\title{
Strong El Niño reduces fruit production of Brazil-nut trees in the eastern Amazon
}

\author{
Dayane Nathália Barbosa PASTANA ${ }^{*} \mathbb{0}$, Érica de Souza MODENA², Lúcia Helena de Oliveira WADT³ ${ }^{3}$ Ezaquiel \\ de Souza NEVES ${ }^{4}$, Lucieta Guerreiro MARTORANO5 ${ }^{5}$, Ana Cláudia LIRA-GUEDES², Rafael Lucas Figueiredo \\ de SOUZA ${ }^{6}$, Felipe Felix COSTA ${ }^{7}$, Anderson Pedro Bernardina BATISTA ${ }^{8}$, Marcelino Carneiro GUEDES ${ }^{2}$ \\ Universidade Federal de Lavras, Rua Aquenta Sol, Lavras - MG, Brazil \\ Empresa Brasileira de Pesquisa Agropecuária, Embrapa Amapá, Rodovia Juscelino Kubitschek, Km 5, n²600, Macapá - AP, Brazil \\ 3 Empresa Brasileira de Pesquisa Agropecuária, Embrapa Rondônia, Rodovia BR 364, Km 5, n5, Porto Velho - RO, Brazil \\ ${ }^{4}$ Universidade Federal do Acre, UFAC, Rodovia BR 364, Km 04, Distrito Industrial, Rio Branco - AC, Brazil \\ Empresa Brasileira de Pesquisa Agropecuária, Embrapa Amazônia Oriental, Rua Enéas Pinheiro 98, Diamantino, Santarém - PA, Brazil \\ ${ }^{6}$ Escola Superior de Agricultura Luiz de Queiroz, ESALQ/USP, Av. Pádua Dias, 235, Agronomia, Piracicaba - SP, Brazil \\ Universidade Federal do Amapá, UNIFAP, Rodovia Juscelino Kubitschek Highway, km 02, Jardim Marco Zero, Macapá - AP, Brazil \\ 8 Instituto Federal de Educação, Ciência e Tecnologia do Amapá, IFAP, Rua Nilo Peçanha, 1263, Cajari, Laranjal do Jari - AP, Brazil \\ * Corresponding author: dayanepastanaa@gmail.com; (iD https://orcid.org/0000-0003-0654-7835
}

\section{ABSTRACT}

The Brazil-nut tree (Bertholletia excelsa) is native to the Amazon rainforest, and its fruit production varies naturally with climatic conditions. Our aim was to evaluate the temporal variation in Brazil-nut production associated with climatic variables, including the strong El Nińo of 2015/2016. The study was carried out in two 9-ha permanent plots in the northeastern Brazilian Amazon from 2007 to 2018: one in forest (12-year monitoring) and the other in savannah/forest transition (eight years). Overall, we monitored fruit production of 205 trees with diameter at breast height $\geq 50 \mathrm{~cm}$. Annual fruit production was related to temporal series (2005-2018) of climatic data (the Oceanic Niño Index; and precipitation and air temperature from two local meteorological stations). Average fruit production per tree in 2017 was eight times lower than in 2015 and two times lower than the general average for both sites, and was significantly associated to the El Niño of 2015/2016, that increased average maximum monthly temperature and reduced the precipitation in the region, extending the dry season from three to six months. Years with higher and lower fruit production per tree coincided in both sites. Annual fruit production was significantly and negatively correlated with thermal anomalies that occurred in the third semester prior to harvest monitoring. Years with higher production were related with predominance of neutrality or the La Niña phenomenon at the global scale, and higher rainfall at the local scale. The relationship of fruit production with climate was independent of the local habitat.

KEYWORDS: Bertholletia excelsa, climate variability, Oceanic Niño Index (ONI), productivity

\section{Forte El Niño reduz a produção de frutos de castanheiras na Amazônia Oriental}

\section{RESUMO}

A castanheira-da-amazônia (Bertholletia excelsa) é nativa da floresta amazônica e sua produção de frutos varia naturalmente com as condiçóes climáticas. Nosso objetivo foi avaliar a variação temporal na produçáo de frutos da castanheira associada a variáveis climáticas, incluindo o forte El Nino de 2015/2016. O estudo foi realizado em parcelas permanentes de 9 ha de 2007 a 2018, uma localizada em floresta (12 anos de monitoramento) e a outra em transiçáo floresta/savana (oito anos). Em total, monitoramos 205 castanheiras com diâmetro à altura do peito $\geq 50 \mathrm{~cm}$. A produçấo anual de frutos foi relacionada a séries temporais (2005-2018) de dados climáticos (o Índice Oceânico Niño; e a precipitação e temperatura do ar de duas estaçóes meteorológicas locais). A produção média por castanheira em 2017 foi oito vezes menor que em 2015 e duas vezes menor que a média geral nos dois sítios, e foi significativamente associada ao El Nińo de 2015/2016, que causou aumento na temperatura máxima mensal e redução na precipitação regional, prolongando a estação seca de três para seis meses. Os anos com maior e menor produção média por castanheira foram os mesmos nos dois ambientes. A produção anual de frutos foi significativa e negativamente correlacionada com as anomalias térmicas ocorridas no terceiro semestre antes da colheita. Anos de maior produção foram relacionados com predominância de neutralidade ou do fenômeno La Niña em escala global, e aumento da precipitação em nível local. A relação entre produção de frutos e clima foi independente do ambiente local.

PALAVRAS-CHAVE: Bertholletia excelsa, variação climática, índice oceânico do Niño, produtividade 


\section{INTRODUCTION}

The Brazil-nut tree (Bertholletia excelsa Bonpl.) has been undergoing a process of domestication by amerindian peoples in the Amazon region since pre-Columbian times (Levis et al. 2018), and has great socioeconomic and cultural importance in the region today (Salomáo 2014). Many extractive communities in the region depend on Brazil nut and its subproducts for family income (De Jesus and Guedes 2017).

The species has a long and synchronous flowering period that occurs during six months (Rathcke and Lacey 1985), normally in the dry season (Tonini 2011). The flower buds yield yellow, hermaphroditic flowers that are pollinized only by specific bees that are able to reach the pollen (Maués et al. 2015). The period between the emission of the first floral buds and maturation of the fruits is about 15 months and fruit dispersion occurs during the rainy season (Moritz 1984; Tonini 2011; Wadt et al. 2018).

There is a large intrapopulational and intraindividual yearly variation in fruit production (Kainer et al. 2006; Pedrozo et al. 2015), which may be due to crown characteristics such as sociological position and vine infestation (Wadt et al. 2015), tree age and size, mainly stem diameter (Neves et al. 2015), soil nutrients (Costa 2018), spatial location of trees and support capacity of different forest typologies (Batista et al. 2019), or interaction with pollinators and climate factors such as rainfall (Wadt et al. 2018).

The rainfall can directly interfere with flowering by affecting flower production, or indirectly by affecting pollinators (Rathcke and Lacey 1985), so that fruit production depends on climatic conditions of the previous year that affect flowering (Tonini 2011). In some species, fruit production is higher in some years and synchronized across large areas, and this can be related to specific climatic conditions during the years preceding the reproductive period (Bogdziewicz et al. 2019). Climate influence can be particularly significant considering scenarios of climate change, with increase of anomalies and frequency of extreme weather events.

The interannual variation in Brazil-nut production directly affects its market supply, price and economic viability. In 2017, the low production of fruits increased the price of an $11-\mathrm{kg}$ can (the reference unit for commercialization) to $\mathrm{R} \$$ 120 (USD 22 according to the 2021 exchange rate), in some regions, compared to the average price of $\mathrm{R} \$ 50$ (USD 9) in 2016. In the northeastern Brazilian Amazon, the 11-kg can was sold for R\$ 200 (USD 38) (Embrapa 2017).

In order to test the hypothesis that the drastic decrease in fruit production of Brazil-nut trees in 2017 was associated with the effects of a strong climatic anomaly, the 2015/2016 El Niño phenomenon, we evaluated Brazil-nut tree production across a series of years (2007-2018). Two Brazil-nut tree populations located in different habitats (forest and savannah/ forest transition) were monitored in the northeastern Brazilian Amazon. Our aims were to: (1) characterize the effect on local climatic conditions of the 2015/2016 El Niño; (2) quantify the average annual production of Brazil nuts in the two populations and relate the yearly variation in production with climatic variables; and (3) evaluate whether the effect of the El Niño on fruit production was affected by the local habitat.

\section{MATERIAL AND METHODS}

\section{Study area}

Data were collected in the Extractivist Reserve of the Cajari River (Resex Cajari), a sustainable-use conservation unit located in the eastern Brazilian Amazon, in the south of the state of Amapá (Funi and Paese 2012) (Figure 1).

In the upland areas of the reserve, clustered Brazil-nut stands naturally occur in vast extensions of rainforest (referred as forest from here on) and transition areas between Amazon rainforest and typical savannah vegetation (savannah with gallery forest) (referred as savannah/forest transition from here on) (IBGE 2012). The climatic typology of the region is Am3, according to the adaptation of the Köppen classification (Martorano et al. 1993).

In the study area, the average annual air temperature is about $25^{\circ} \mathrm{C}$ and average annual rainfall is $2,300 \mathrm{~mm}$, distributed in two distinct seasons: a rainy season (January to July), and a dry season (August to December), when rainfall is lower and may lack completely in some months. September through November is the period with the lowest average rainfall $(<100 \mathrm{~mm}$ per month), and includes prolonged

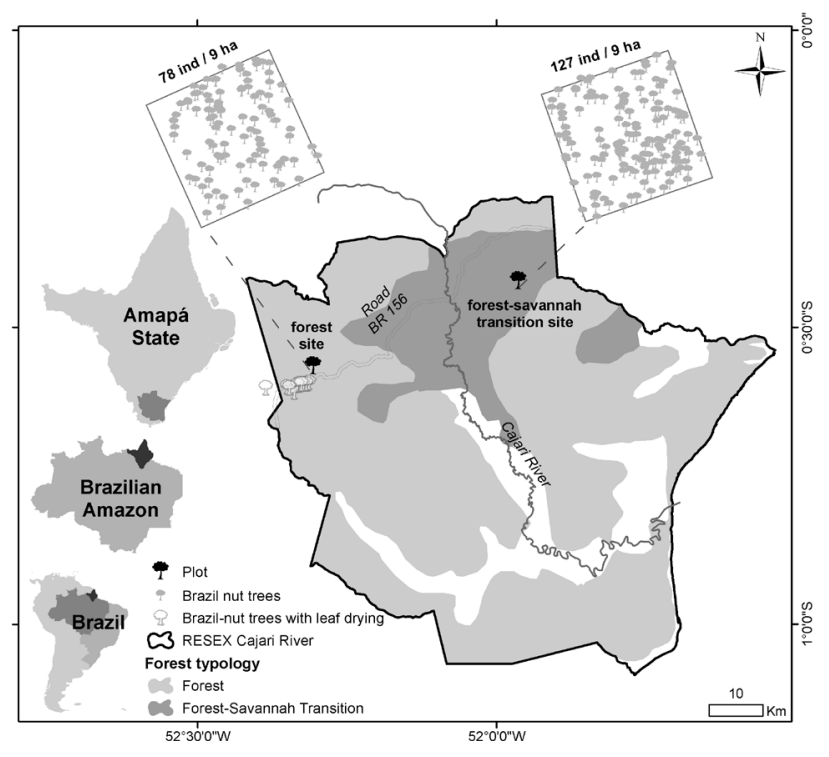

Figure 1. Location of the study area in the Brazilian Amazonian state of Amapá. The larger area represents the contour of the Extractive Reserve of the Cajari River (Reserva Extrativista do Rio Cajari) (Resex Cajari), showing the location of the two 9-ha permanent sampling plots within natural stands of Brazil-nut tree (Bertholletia excelsa) in an area of forest and an area of savannah/forest transition. 
drought periods with no rainfall (Da Cunha et al. 2010). The main soils in the region are red-yellow dystrophic oxisols with a clayey texture, yellow dystrophic oxisols with a loamy texture, and red-yellow ultisols (RadamBrasil 1974). The soil was classified as eutrophic red-yellow ultisol in the forest plot and as red-yellow petroplintic dystrophic oxisol in the savannah/forest transition, which has lower support capacity (Oliveira Jr. et al. 2021).

\section{Brazil-nut fruit yield}

Data were collected in two permanent plots of 9 ha each $(300 \mathrm{~m} \times 300 \mathrm{~m})$, one located in natural forest (monitored from 2007 to 2018) and the other in natural savannah/forest transition (monitored from 2010 to 2018, except 2012). All Brazil-nut trees in each plot with $\geq 31 \mathrm{~cm}$ circumference at breast height - $\mathrm{CBH}$ (at $1.3 \mathrm{~m}$ above the soil) were identified and mapped. CBH was measured in 2018 using a metric tape with a precision of $1 \mathrm{~mm}$, and values were converted to diameter at breast height $(\mathrm{DBH}=\mathrm{CBH} / \pi)$. The inclusion criterion for this study was $\mathrm{DBH} \geq 50 \mathrm{~cm}$, as Brazil-nut trees of this size are considered to have production potential (Wadt et al. 2005). Productive trees were classified into DBH classes, which are assumed to be related to age: Class I = DBH 50 $100 \mathrm{~cm} ; \mathrm{II}=100.1-150 \mathrm{~cm}$ III $=150.1-200 \mathrm{~cm}$, and IV $=>200.1 \mathrm{~cm}$ (Wadt et al. 2005).

Both populations are explored by local agroextractivist communities, who harvest fallen fruit each year. The monitored trees were visited annually after the period of fruit fall (second half of February). For safety reasons, the agroextractivists do not enter the Brazil-nut tree stand while the fruits are falling from the trees. Before collection, we assumed that only native fauna (mainly agoutis) removed the fruits (Wadt et al. 2018). From the end of fruit-falling onwards, we accompanied the extractivists into the plots during fruit collection. We monitored the effective production, i.e. the number of fruits available for collection by the extractivists after the fruits stopped falling from the trees, referred from here on as fruit production.

The fruit production of each individual tree was quantified by collecting all healthy fruits on the ground under the projection of the crown (Supplementary Material, Table S1). We excluded immature fruits (small and light), fruits damaged by animals (with tooth marks from agoutis and beak marks from macaws) and fruits from the previous year's harvest (much lighter then freshly fallen fruits and without bark).

\section{Meteorological variables}

A historical series (from 2005 to 2018) of monthly mean air temperature, maximum temperatures and precipitation were obtained from Instituto Nacional de Meteorologia (the Brazilian National Meteorological Institute), from meteorological station nr. 82098 located in Macapá, the capital of Amapá (INMET 2021a). This station is the nearest to Resex Cajari (121 km in a straight line) that contains a long series of data. Data collected at a station installed in the Resex Cajari and monitored by Sobrinho (2017), from April 2015 to March 2016 March were also used.

To analyse the effect of climate anomalies, we used the Oceanic Niño Index (ONI), which is calculated using data from floating monitoring stations installed in the Equatorial Tropical Pacific Ocean, in the region of Niño 3.4, between the latitudes $5^{\circ} \mathrm{N}$ and $5^{\circ} \mathrm{S}$, and longitudes $120^{\circ}$ to $160^{\circ} \mathrm{W}$. The data are available for overlapping quarterly periods from the US National Aeronautics and Space Administration (https:// origin.cpc.ncep.noaa.gov/products/analysis_monitoring/ ensostuff/ONI_v5.php). Positive anomalies $\left(>0.5^{\circ} \mathrm{C}\right)$ in the sea surface temperatures (SST), which are characterized as an El Niño on a global scale, occurred between October 2015 and June 2016. These anomalies were $\geq 2.5^{\circ} \mathrm{C}$ during the quarters Oct-Nov-Dec 2015 (OND2015), Nov-Dec-Jan 2016 (NDJ2016) and Dec-Jan-Feb 2016 (DJF2016).

In order to standardize our local metreorological data with the ONI, we calculated the three-month running mean of rainfall and mean and maximum air temperature for the same periods used for the ONI.

\section{Statistical analyses}

The fruit production data did not comply with the requirements of homogeneity of variance and normal distribution according to the Levene and Shapiro-Wilk tests, respectively.

The association of annual fruit production per plot with the quarterly averages of the climatic variables (ONI, maximum temperature, and rainfall) and the maximum temperature and rainfall averages in the first to fourth semester preceding harvest was analyzed by Pearson correlation. In each correlation, the values of annual fruit production per plot (12 values for forest and 8 values for forest/savannnah) were correlated with quarterly or grouped semiannual periods prior to the year of each harvest. For example, for the production of 2007, the corresponding values of the climatic variables used in correlations ranged from the quarters Dec 2006-Feb 2007 to Jan-Mar 2005, while for the production of 2018, in the same way, the values ranged from the quarters of Dec 2017-Feb 2018 to Jan-Mar 2016.

We used generalized linear models (GLM) to test for differences in average fruit production per tree among the years with data for both areas, considering two prediction factors (habitat and DBH class). The Mann-Whitney U test was used to compare the production per tree between the two sites in 2017 (the year with the notable decrease in production) and in 2018 (when production increased again). The difference between the distribution of diametric classes in the two habitats was tested using a chi-square test. 
All analyzes were done using the $\mathrm{R}$ software ( $\mathrm{R}$ Core Team 2020). For the Levene and Shapiro-Wilk tests, we used the car package (Fox and Weisberg 2019), for the GLM, we used the tidyverse package (Wickham et al. 2019), for the Pearson correlations, we used the PerformanceAnalytics (Carl and Peterson 2020) and ggpubr packages (Kassambara 2020), for the Mann-Whitney U test, we used the dpylr (Wickham et al. 2021) and rstatix packages (Kassambara 2021).

\section{RESULTS}

\section{Characterization of the El Niño in the study area}

The local increase in the average maximum monthly temperature during the second semester of 2015 and the first months of 2016 in the study area corroborate the description of this period as a strong El Niño. During this period, the monthly maximum temperatures were always higher than in any other year of the monitoring period and were also higher than the normal climatological pattern from 1961 to 1990 for the Macapá meteorological station (INMET 2021b) (Figure 2).

The average monthly of the maximum temperature in $2015 / 2016\left(32.6^{\circ} \mathrm{C}\right)$ was $2.1{ }^{\circ} \mathrm{C}$ higher, and the monthly average of the minimum temperature $\left(22.9^{\circ} \mathrm{C}\right)$ was $0.3{ }^{\circ} \mathrm{C}$ lower than in the other years. The precipitation regime was also altered. In 2015, the drought period (precipitation < $100 \mathrm{~mm} \mathrm{month}^{-1}$ ), which normally lasts three months, lasted six months, from July to December, with more than 100 continuous days without rain. There was a similar variation pattern in precipitation and temperature data from the weather stations in Resex Cajari and Macapá (Figure 3).

The total accumulated rainfall in one year (April 2015 to March 2016) at the Resex Cajari station was $2,818 \mathrm{~mm}$ (Sobrinho 2017), and 2,564 $\mathrm{mm}$ for the same period at the Macapá station (INMET 2021a). Despite being near the climatological normal, the precipitation was more irregularly distributed than normal, amplifying the drought effect through the reduced rainfall in the second semester of 2015, in association with the El Niño that occurred in this period.

\section{Relationship of fruit production with climatic variables}

There were significant negative correlations of fruit production with the Oceanic Niño Index and monthly maximum temperatures, mainly during the third semester before harvest (Table 1).

The significant correlation with monthly maximum temperatures started in the quarter beginning with July in the second year before harvest and up to the quarter beginning with June in the year before harvest. The begin and end of the negative relationships occurred first with the temperature anomaly in the Pacific Ocean (ONI), than with maximum

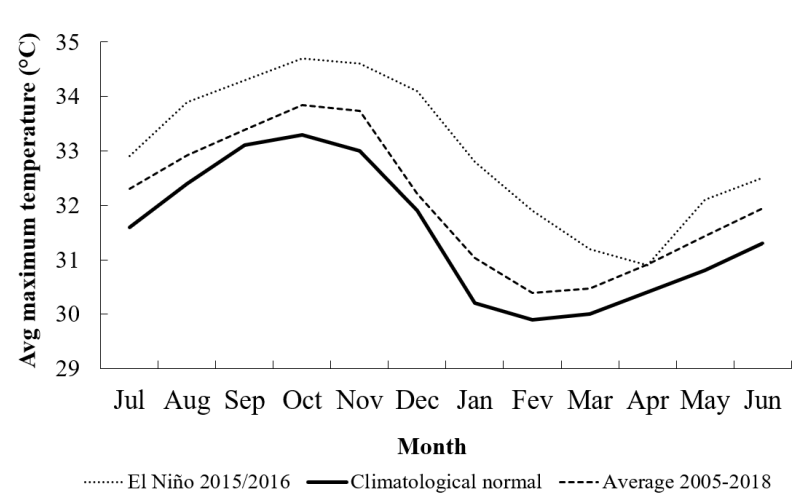

Figure 2. Monthly maximum temperature in the study region in southern Amapá state (Brazil) from July to June during the 2015/2016 El Niño, averaged for the whole study period (2005-2018) and for the period used to calculate the climatological normal (1961 to 1990). Source: INMET (2021b)

temperature and precipitation. Comparing the beginning and end of significant correlations of production with ONI, there was a 2-month delay at the beginning and a 4-month delay at the end of the period when the local temperature was significantly correlated.

There was a significant negative correlation $(r=-0.60, p=$ $0.004, \mathrm{n}=20$ ) of the total annual fruit production per plot with the ONI during the less-rainy period in the third semester before harvest (Figure 4).

The year with the lowest fruit production in both areas (2017) was associated with an increase of more than $2{ }^{\circ} \mathrm{C}$ in the temperature of the ocean during the dry season of 2015 , characterized as the strong El Niño. The years of greatest production (2012, 2015 and 2018) were related to previous periods of normal or negative ONI values.

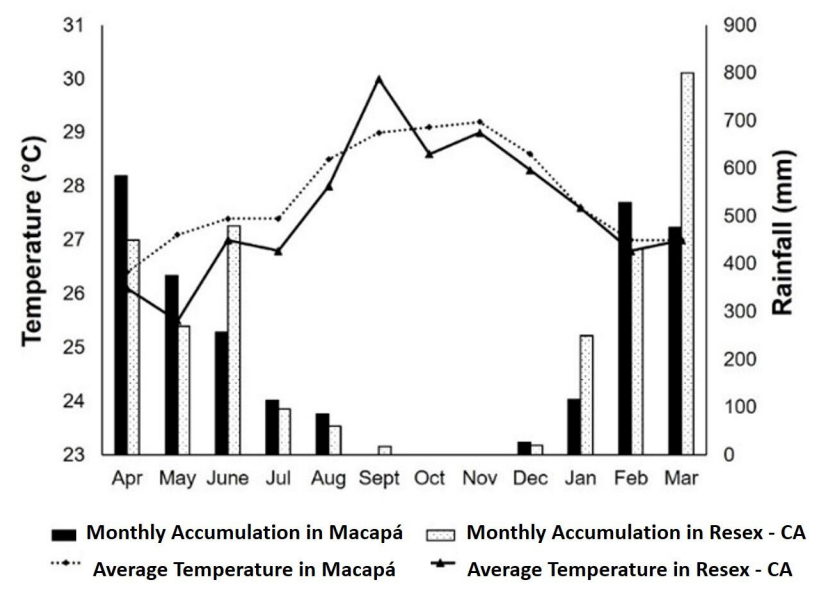

Figure 3. Monthly rainfall and temperature average from April 2015 to March 2016 at meteorological stations in Resex Cajari and Macapá, in Amapá state, Brazil. Source: Sobrinho (2017); INMET (2021a). 
Table 1. Pearson correlation coefficients and $p$-values for the relationship between annual fruit production of Brazil nut trees (Bertholletia excelsa) in a natural forest stand (from 2007 to 2018) and a forest/savannah transition area (2010, 2011 and 2013 to 2018) ( $n=20)$ in southern Amapá, in the eastern Brazilian Amazon, with quarterly running averages of Oceanica Niño Index, quarterly running averages of maximum temperature ( $T$ max) and quarterly running averages of precipitation in the study area in the two years prior to fruit harvest. The quarterly values are grouped by semester. The number in the code for correlation period indicates whether it is the first, second, third or fourth semester prior to harvest. The three letters indicate the three months that compose each quarter period (e.g. DJF = December, January, February; NDJ = November, December, January; and so on); acc = accumulated value for the semester; average = averaged value for the semester. Significant values are in bold.

\begin{tabular}{|c|c|c|c|c|c|c|}
\hline \multirow{2}{*}{$\begin{array}{c}\begin{array}{c}\text { Correlation } \\
\text { period }\end{array} \\
1 \mathrm{DJF}\end{array}$} & \multicolumn{2}{|c|}{ ONI $\left({ }^{\circ} \mathrm{C}\right)$} & \multicolumn{2}{|c|}{$T \max \left({ }^{\circ} \mathrm{C}\right)$} & \multicolumn{2}{|c|}{ Precipitation (mm) } \\
\hline & 0.05 & $p=0.820$ & 0.41 & $p=0.069$ & -0.47 & $p=0.067$ \\
\hline $1 \mathrm{NDJ}$ & 0.09 & $p=0.707$ & 0.53 & $p=0.015$ & -0.45 & $p=0.078$ \\
\hline $1 \mathrm{OND}$ & 0.10 & $p=0.664$ & 0.11 & $p=0.639$ & -0.21 & $p=0.429$ \\
\hline $1 \mathrm{SON}$ & 0.09 & $p=0.691$ & -0.18 & $p=0.440$ & 0.22 & $p=0.406$ \\
\hline $1 \mathrm{ASO}$ & 0.11 & $p=0.647$ & -0.27 & $p=0.250$ & 0.22 & $p=0.422$ \\
\hline $1 \mathrm{JAS}$ & 0.10 & $p=0.674$ & -0.32 & $p=0.169$ & 0.35 & $p=0.178$ \\
\hline $1 \mathrm{acc}$ & - & - & - & - & -0.25 & $p=0.348$ \\
\hline 1 average & - & - & 0.15 & $p=0.525$ & 0.62 & $p=0.010$ \\
\hline $2 \mathrm{JJA}$ & 0.07 & $p=0.772$ & -0.42 & $p=0.063$ & 0.64 & $p=0.003$ \\
\hline $2 \mathrm{MJJ}$ & 0.04 & $p=0.860$ & -0.52 & $p=0.019$ & 0.33 & $p=0.210$ \\
\hline $2 \mathrm{AMJ}$ & -0.14 & $p=0.566$ & -0.49 & $p=0.028$ & 0.07 & $p=0.795$ \\
\hline 2 MAM & -0.40 & $p=0.084$ & -0.59 & $p=0.006$ & 0.25 & $p=0.350$ \\
\hline $2 F M A$ & -0.57 & $p=0.009$ & -0.68 & $p=0.001$ & 0.19 & $p=0.484$ \\
\hline $2 \mathrm{JFM}$ & -0.61 & $p=0.004$ & -0.76 & $p<0.001$ & 0.46 & $p=0.072$ \\
\hline 2 acc & - & - & - & - & 0.13 & $p=0.624$ \\
\hline 2 average & - & - & -0.64 & $p=0.002$ & 0.04 & $p=0.888$ \\
\hline $3 \mathrm{DJF}$ & -0.61 & $p=0.005$ & -0.71 & $p<0.001$ & 0.04 & $p=0.895$ \\
\hline 3 NDJ & -0.60 & $p=0.006$ & -0.66 & $p=0.002$ & -0.04 & $p=0.874$ \\
\hline 3 OND & -0.58 & $p=0.008$ & -0.64 & $p=0.002$ & 0.37 & $p=0.161$ \\
\hline $3 \mathrm{SON}$ & -0.58 & $p=0.007$ & -0.71 & $p<0.001$ & 0.40 & $p=0.128$ \\
\hline $3 \mathrm{ASO}$ & -0.61 & $p=0.004$ & -0.62 & $p=0.004$ & 0.18 & $p=0.514$ \\
\hline $3 \mathrm{JAS}$ & -0.62 & $p=0.004$ & -0.59 & $p=0.006$ & 0.04 & $p=0.870$ \\
\hline $3 \mathrm{acc}$ & - & - & - & - & 0.01 & $p=0.974$ \\
\hline 3 average & - & - & -0.77 & $p<0.001$ & 0.36 & $p=0.175$ \\
\hline $4 \mathrm{JJA}$ & -0.64 & $p=0.002$ & -0.29 & $p=0.207$ & 0.46 & $p=0.073$ \\
\hline $4 \mathrm{MJJ}$ & -0.56 & $p=0.010$ & 0.04 & $p=0.855$ & 0.18 & $p=0.503$ \\
\hline $4 \mathrm{AMJ}$ & -0.25 & $p=0.282$ & 0.26 & $p=0.270$ & -0.23 & $p=0.392$ \\
\hline 4 MAM & 0.05 & $p=0.818$ & 0.30 & $p=0.198$ & 0.22 & $p=0.412$ \\
\hline 4 FMA & 0.26 & $p=0.269$ & 0.26 & $p=0.262$ & -0.25 & $p=0.348$ \\
\hline 4 JFM & 0.31 & $p=0.185$ & 0.22 & $p=0.351$ & 0.46 & $p=0.072$ \\
\hline $4 \mathrm{acc}$ & - & - & - & - & 0.18 & $p=0.514$ \\
\hline 4 average & - & - & 0.16 & $p=0.491$ & 0.22 & $p=0.412$ \\
\hline
\end{tabular}

The strongest negative correlation of fruit production $(\mathrm{n}=20, \mathrm{r}=-0.77, \mathrm{p}<0.001, \mathrm{n}=20)$ at the local scale was obtained with average maximum temperature (Table 1; Figure 5a) during the dry period in the third semester before harvest, when the trees were flowering and forming new fruits. Average rainfall was positively and significantly $(r=0.64, p=0.003$, $\mathrm{n}=20$ ) correlated with fruit production in the first semester

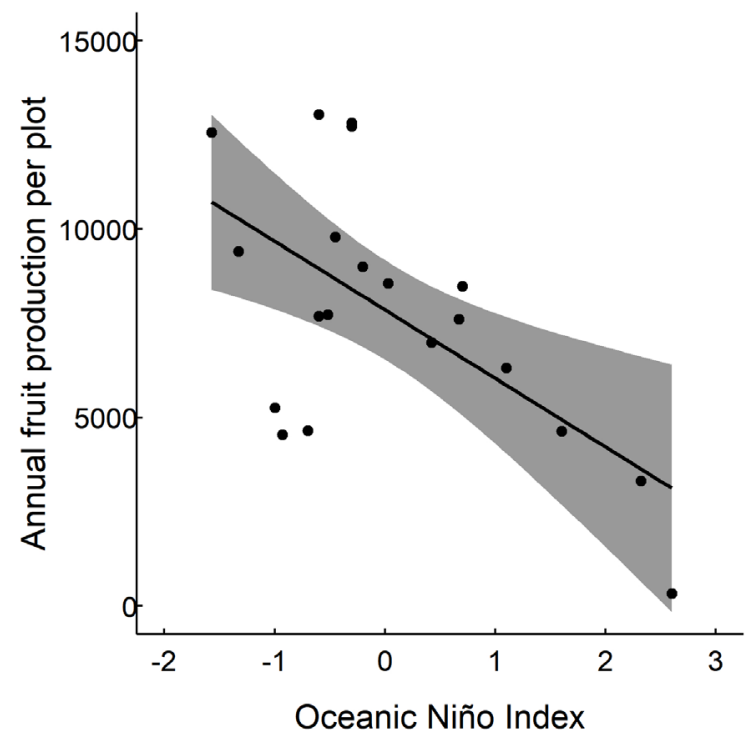

Figure 4. Correlation of total annual fruit production per plot in two natural stands of Brazil nut trees (Bertholletia excelsa) $(n=20)$ with the Oceanic Niño Index during the third semester before harvest. Data from extractivist harvest monitoring for 12 years in a forest area (2007 to 2018) and for eight years in a forest/savannah transition area (2010,2011 and 2013 to 2018) in southern Amapá (eastern Brazilian Amazon). The grey area indicates the 95\% confidence interval.

and first quarter of the second semester before harvest (Table 1; Figure $5 b)$.

\section{Comparison between sampling sites}

The fruit production per tree was differed significantly among the years with data for both areas, considering habitat and DBH class as prediction factors $(\mathrm{F}=2940.2, \mathrm{df}=1719$, $p<0,001$. Fruit production per tree was significantly lower in the forest/savannah site than in the forest site in 2017 (W $=10222, \mathrm{p}<0.001)$, when overall production in the forest $/$ savannah site was $97 \%$ lower than in 2016 , while it was only $53 \%$ lower in the forest site (Figure 6a). Fruit production per tree was slightly higher in the savannah/forest site than in the forest site in 2018, but the difference was not significant (W $=5826.5, \mathrm{p}=0.366$ ) (Figure 6b).

The frequency distribution of trees in the diametric classes differed significantly between the populations (X-squared $=1498.5, \mathrm{df}=174, \mathrm{p}<0.001$ ) (Figure 7a). Average fruit production per tree was higher in all diametric classes in the forest than in the forest/savannah (Figure 7b). Fruit production was highest in intermediate-sized trees of the 100$150-\mathrm{cm} \mathrm{DBH}$ class in the forest/savannah transition, and in older and larger trees of the 150-200-cm DBH class in the forest. In both habitats, maximum average fruit production occurred in intermediate-sized trees (figure 7a,b). In 2017, average fruit production per tree in the forest was similar to the interannual average production in all size classes, while there was a sharp drop in this parameter in all size classes in the savannah/forest transition (Figure 7c). 

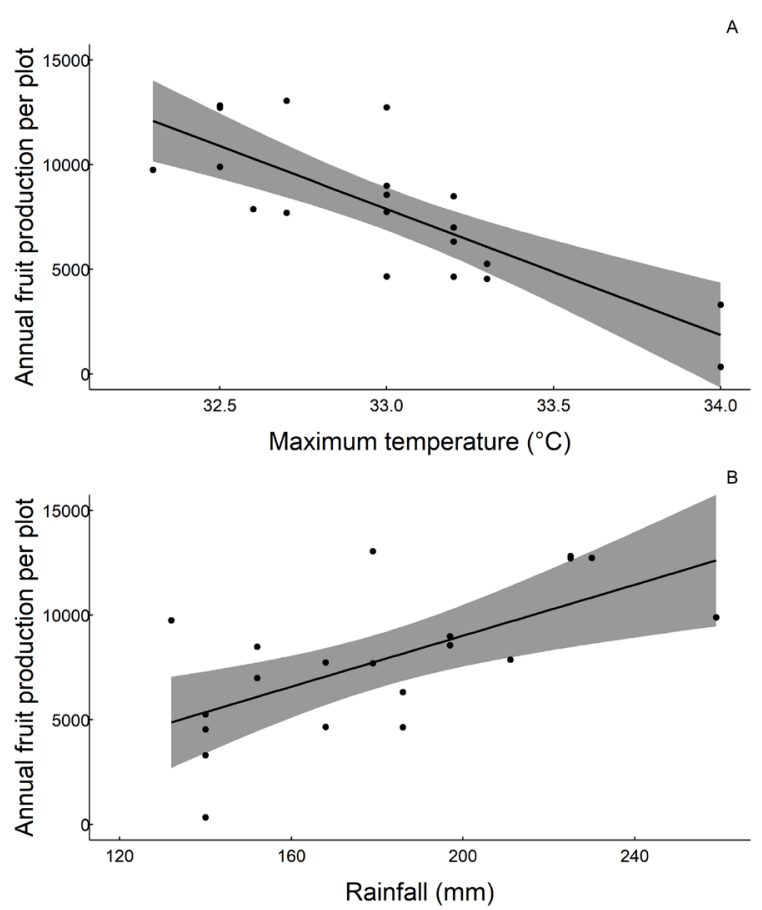

Figure 5. Correlation of total annual fruit production per plot in two natural stands of Brazil-nut trees (Bertholletiaexcelsa) $(n=20)$ with average local maximum temperature in the third semester before harvest (A); and with local precipitation in the quarter June-July-August of the year before harvest (B). Data from extractivist harvest monitoring for 12 years in a forest area (2007 to 2018) and for eight years in a forest/savannah area (2010, 2011 and 2013 to 2018) in southern Amapá (eastern Brazilian Amazon). The grey area indicates the 95\% confidence interval.
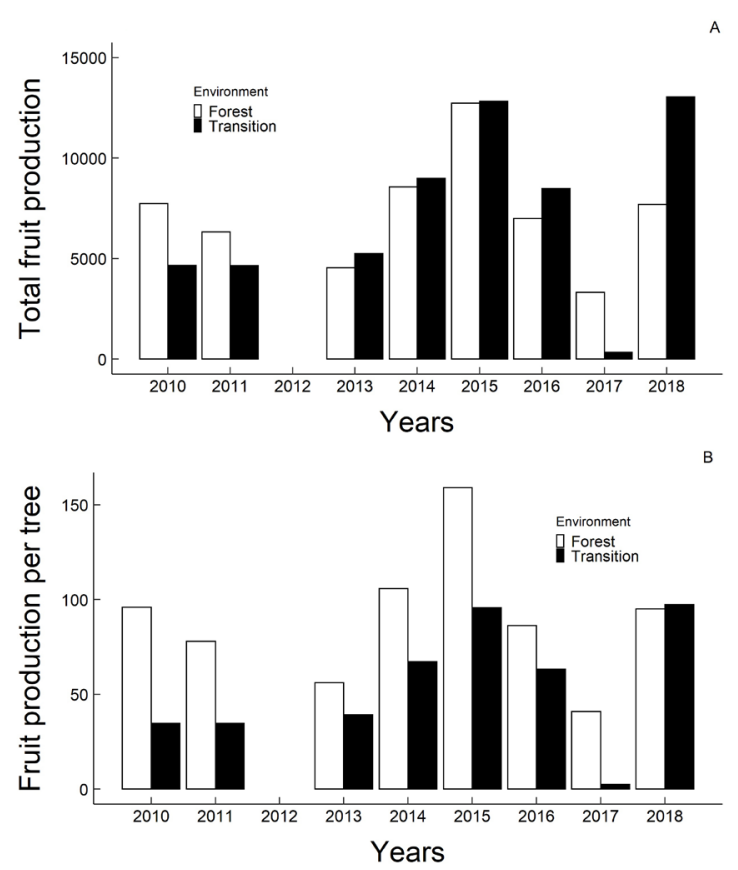

Figure 6. Total production per plot (A) and average fruit production per tree (B) of Brazil nut in 2010, 2011 and 2013-2018 in two 9-ha permanent sampling plots in a forest site and a savannah/forest transition site in Resex Cajari, southern Amapá, eastern Brazilian Amazonia.
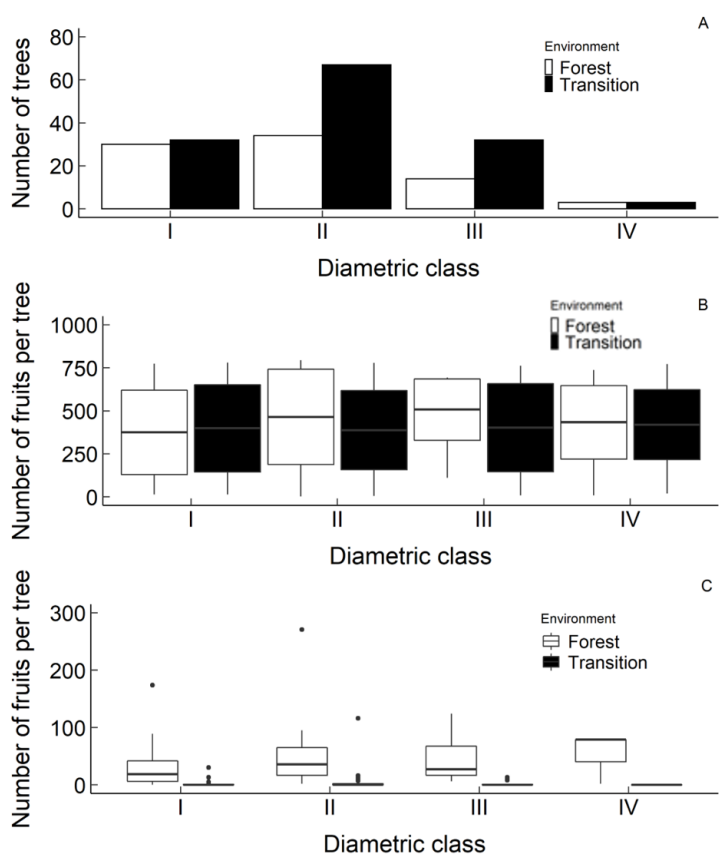

Figure 7. Number of productive Brazil-nut trees (A); interannual average fruit production per tree $(2010,2011,2013-2018)(B)$; and average fruit production per tree in 2017 (C) per DBH class in two 9-ha permanent sampling plots in a forest site (78 trees) and a savannah/forest transition site (127 trees) in Resex Cajari, southern Amapá, eastern Brazilian Amazonia. DBH classes: I = 50.1 - 100 $\mathrm{cm} ;\|=100.1-150 \mathrm{~cm} ;\| I=150.1-200 \mathrm{~cm} ; I V=>200.1 \mathrm{~cm}$. The within-box line represents the average value (B) or median value (C), the box the standard deviation (B) or the $50 \%$ percentile (C), and the bars the confidence interval. The dots indicate outlier values.

\section{DISCUSSION}

\section{Characterization of El Niño in the study area}

The observed increase in air temperature in the Cajari and Macapá meteorological stations is in agreement with the increase in average temperatures recorded around the world in 2015, possibly in association with the El Niño phenomenon (Fonseca et al. 2017). The 2015/2016 El Niño was the strongest of the last 50 years, and affected the entire Amazon region (Vogt et al. 2016). Another study conducted in Amapá related the 2015/2016 El Niño with decreases in regenerating individuals $(\mathrm{DBH}<5 \mathrm{~cm})$ density and with physiological stress of another native tree species, Mora paraensis (Miranda et al. 2018). We also observed the drying and senescence of leaves of Brazil-nut trees in the forest area (see Figure 1) in the years following the El Niño, until the beginning of 2018, a period of strong rainfall, which is not the normal period for leaf abscission and resprouting in this species.

Extreme climatic events such as droughts associated with temperature anomalies in the equatorial Pacific Ocean occur with distinct frequencies in different regions of the planet. In the Amazon, these events occur approximately every five years. Besides 2015, there were severe droughts in the region in 2005 and 2010 (Marengo 2007; Zaho et al. 2017; Zeng 
et al. 2008). The negative effect of the 2010 drought, which occurred due to increased SST of the tropical North Atlantic (Marengo and Espinoza 2016; Aragão et al. 2018), on the fruit production in 2011 was also observed in our study area (see Figure 4). After 2017, 2011 was the year with the second lowest Brazil-nut production.

The eastern Amazon is more sensitive to climate change than other Amazon regions and is predicted to suffer most alterations due to its effects (Nobre 2008). However, strong climatic variations such as those in 2010 and 2015 can have pan-Amazonian effects on three large epicenters in southwestern Amazonia, north-central Bolivia, and Brazil's Mato Grosso state (Lewis et al. 2011; Vogt et al. 2016), and can thus affect the basin-wide fruit production of Brazil nut or other species that have great importance for the economy and food security in Amazonia.

The reduction in production, and the resulting low supply of Brazil nuts in a strong market with rising prices increased social pressure and conflicts in the extractivist units. In Resex Cajari, the value of the standard measure unit of $11 \mathrm{~kg}$ of Brazil nut incresed from USD 10 in 2016 to USD 38 in 2017 (pers. obs. by the authors). There were reports of invasions of collection areas by non-residents of the Resex Cajari, which had never happened before, and of clandestine gold mining in the Jari Ecological Station (ESEC Jari) located near Resex Cajari. Furthermore, there were reports of theft of Brazil nuts that had already been bagged and placed along forest roads ready for transport to market, which increased the level of danger in traditional communities and reduced the income of many families who are dependent on Brazil-nut extractivism.

\section{Relationship of fruit production with climatic variables}

In 2017 there was a drastic decrease in Brazil-nut production across the Amazon region, with a total of 21,651 tons that was 37\% below the 10-year average (2010-2019) (IBGE 2021). This unprecedented decrease occurred in all states of the Brazilian Amazon, and in the Amazon region outside Brazil (EMBRAPA 2017).

Our results showed that Brazil-nut fruit production decreased drastically in 2017 and was associated with temperature anomalies. Maximum temperature is the most important predictor of biomass productivity reduction and has a greater impact per ${ }^{\circ} \mathrm{C}$ in the hottest forests $\left(>32.2^{\circ} \mathrm{C}\right.$ ) (Sullivan et al. 2020), as was the case in our forest plots, where we recorded values near $35^{\circ} \mathrm{C}$ and increases of more than 2 ${ }^{\circ} \mathrm{C}$ in maximum temperature during the El Niño.

The development, maturation, and dispersion of Brazilnut fruits takes up to 15 months (Moritz 1984), thus the fruits harvested in 2017 initiated their formation in the second semester of 2015, when the El Niño occurred, which explains the association of the low fruit production in 2017 with this semester. As flowering occurs in the second semester (Maués et al. 2015), the temperature increase can cause an increase in respiration above the normal level needed for photosynthesis, leading to the consumption of carbohydrate reserves, flower abscission and consequent reduction in fruit production and fruit sweetnesss (Matos et al. 2019).

Higher temperatures in the phenological activity period can also affect pollinator survival (Rathcke and Lacey 1985). There is evidence of recent declines in the abundance and richness of pollinator species, mainly of bees (Novais et al. 2016), which are polinators of Brazil nut (Maués et al. 2015; Santos and Absy 2012). The decline in pollinators has been shown to be associated with temperature increases (Becker et al. 2018).

The positive correlation of fruit production with rainfall in the eight months preceding harvest is likely related to that these months correspond to the period of final growth and maturation of fruits that will be dispersed in the beginning of the following year. Higher rainfall rates during this period can accelerate the final maturation of fruits and aid in the process of breaking off from branches. Thus, when the rainy season is prolonged until August and there is more rain in the quarter June-July-August, during the final phase of maturation of fruits, fruit production improves. The years of greater fruit production (2012, 2015 and 2018) were related to previous periods characterized as a La Niña at a global level, which is associated with higher rainfall in the eastern Amazon (Villar et al. 2008). Likewise, in the state of Roraima (Brazil), during monitoring of Brazil-nut fruit production from 2006 to 2012, a much higher production was observed in 2012 (Tonini and Pedrozo 2014). The latter authors report that Brazil-nut trees appear to have years of peak production (mast years) and emphasize that long-term studies are needed for species with masting behavior, as they are particularly sensitive to climate changes that can alter the frequency of fruit production (Tonini and Pedrozo 2014).

In the state of Acre (Brazil) and in Bolivia, significant reductions in Brazil-nut fruit production were also related with decrease in rainfall and prolonged drought in previous years (Kainer et al. 2007), and in the state of Roraima, higher rainfall in September had a positive effect on Brazil-nut fruit production (Tonini 2011), corroborating our results on the effect of rainfall. 


\section{Comparison between sampling sites}

Although the temporal variation in fruit production followed a similar pattern in both study sites, average fruit production per tree was generally higher in the forest, so that total fruit production was frequently similar or higher than in the forest/savannah plot, despite the fact that there were 38\% less trees and a higher proportion of young trees (at an early stage of reproduction) in the forest plot. This indicates that the forest habitat has greater support capacity for Brazil-nut trees. The soil in the forest area has better soil quality, with higher levels of soil organic matter and nutrient availability that in the forest/savannah transition soil, which has higher acidity and concentration of lateritic concretions (Oliveira Jr. et al., 2021; Sobrinho 2017).

The greater support capacity of the forest likely also favored the higher average fruit production in larger and older trees. The trees in the forest/savannah transition had maximum fruit production at intermediate sizes of 100-150 $\mathrm{cm} \mathrm{DBH}$, as was also reported for Brazil-nut trees by Neves et al. (2015). Another factor that may contribute to higher individual productivity is the lower density of Brazil-nut trees in the forest habitat. The higher density of Brazil-nut trees in the forest/savannah transition increases the intraspecific and interspecific competition for nutrients and, consequently, the rate of exported nutrients in the previous harvest (Oliveira Jr. et al. 2021).

Our results indicate that Brazil-nut trees respond with a significant decrease in fruit production to extreme El Niño events, and that this response (but also the ensuing recovery) is more pronounced in enrironments with lower support capacity. In this context, the prospect of an increase in the frequency of extreme climatic events that affect the stability and functioning of ecosystems (Meir et al. 2015) can have a significant negative impact on Brazil-nut productivity and, consequently, on the livelyhood of extractivist communities that depend on it. It is thus important to further understand and monitor the effects of future frequency and magnitude of El Niños on the Brazil nut production chain, as well as on the behavior and survival of $B$. excelsa trees and their forest habitat.

Although fruit production declined in both sampling areas in 2017, the intensity of the decline was greater in the savannah/forest transition, but capacity for recuperation in this area the next year was also relatively higher, as average production per tree was equivalent to that in the forest in 2018, when it had been below average productivity in the forest in all previous years. This striking recovery capacity of fruit production in Brazil-nut trees in the transition site may be due to that there was very little nutrient export in 2017, allowing for internal accumulation in the trees and subsequent increased cycling of nutritive elements used to form fruits for the next harvest (Fenner 1998). This suggests that there is proportionality between decrease and recovery in Brazil nut productivity in both habitats in response to major climatic impacts, and that the recovery rate is more related to habitat conditions during the previous than the current harvest, depending on the support capacity of the habitat.

\section{CONCLUSIONS}

A strong El Niño in 2015/2016 was associated with a significant increase in maximum air temperatures in the eastern Brazilian Amazon, which in turn was associated with a reduction in Brazil-nut fruit production in the following harvest. In a series of 12 years of harvest monitoring, years with greater fruit production were related to preceding periods of normal or lower-than-normal temperatures, associated with predominance of La Niña at a global level, and higher rainfall at a local level. Brazil-nut trees within forest had higher individual productivity than trees in savannah/forest transition, but trees in both habitats responded in the same way to climatic variability.

\section{ACKNOWLEDGMENTS}

We thank our agroextractivist partners who allowed us to work on their properties, and the Instituto Chico Mendes de Conservação da Biodiversidade (ICMBIo), as the manager of Resex Cajari. We also thank Conselho Nacional de Desenvolvimento Científico e Tecnológico $(\mathrm{CNPq})$ and Coordenação de Aperfeiçoamento de Pessoal de Nivel Superior (CAPES) for the scholarships to the students who participated in this project. Finally, we thank Empresa Brasileira de Pesquisas Agropecuária (EMBRAPA) for funding through the following projects: Kamukaia I (02.04.01.006.00.03) and II (02.07.06.004.00.02), MapCast (02.13.05.001.00.03), MelhorCast (02.13.05.015.00.02) and EcoGenCast (02.13.05.017.00.04). This paper was translated by Troy Patrick Beldini.

\section{REFERENCES}

Aragão, L.E.O.C.; Anderson, L.O.; Fonseca, M.G.; Rosan, T.M.; Vedovato, L.B.; Wagner, F.H.; et al. 2018. 21st Century droughtrelated fires counteract the decline of Amazon deforestation carbon emissions. Nature Communications, 9: 536.

Batista, A.P.B.; Scolforo, H.F.; Mello, J.M. de; Guedes, M.C.; Terra, M.C.N.S.; Scalon, J.D.; et al. 2019. Spatial association of fruit yield of Bertholletia excelsa Bonpl. trees in eastern Amazon. Forest Ecology and Management, 441: 99-105.

Becker, T.; Pequeno, P.A.C.L.; Carvalho-Zilse, G.A. 2018. Impact of environmental temperatures on mortality, sex and caste ratios in Melipona interrupta Latreille (Hymenoptera, Apidae). The Science of Nature, 105: 55. doi.org/10.1007/s00114-018-1577-6

Bogdziewicz, M.; Szymkowiak, J.; Fernández-Martínez, M.; Peñuelas, J.; Espelta, J.M. 2019. The effects of local climate on the correlation between weather and seed production differ in two species with contrasting masting habit. Agricultural and Forest Meteorology, 268: 109-115. 
Carl, B.G.; Peterson, P. 2020. PerformanceAnalytics: Econometric Tools for Performance and Risk Analysis. R package version 2.0.4. (https://cran.r-project.org/package=PerformanceAnalytics).

Costa, F.F. 2018. Ocorrência e estrutura vertical de florestas com castanheiras na amazônia brasileira. Master's thesis, Universidade Federal de Macapá, Brazil. 88p. (http://repositorio.unifap. br:8080/handle/123456789/212)

Da Cunha, A.C.; Souza, E.B. de; Cunha, H.F.A. 2010. Tempo, Clima e Recursos Hídricos: Resultados do Projeto REMETAP no Estado do Amapá. v.20, 2nd ed. IEPA, Macapá, p.83-96p.

De Jesus, F.; Guedes, M. 2017. Forest loss and matrix composition are the major drivers shaping dung beetle assemblages in a fragmented rainforest. Landscape Ecology, 31: 843-854.

Embrapa. 2017. Empresa Brasileira de Pesquisa Agropecuária. Pesquisa aponta queda de $70 \%$ na produção de castanha-daamazônia. (https://www.embrapa.br/busca-de-noticias/-/ noticia/26131296/pesquisa-aponta-queda-de-70-na-producaode-castanha-da-amazonia). Accessed on 12 May 2018.

Fenner, M. 1998. The phenology of growth and reproduction in plants. Perspectives in Plant Ecology Evolution and Systematics, 1: 78-91.

Fonseca, M.G.; Anderson, L.O.; Arai, E.; Shimabukuro, Y.E.; Xaud, H.A.M.; Xaud, M.R.; et al. 2017. Climatic and anthropogenic drivers of northern Amazon fires during the 2015-2016 El Niño event. Ecological Applications 27: 2514-2527.

Fox, J.; Weisberg, S. 2019. An $\{R\}$ Companion to Applied Regression. 3rd ed. Sage, Thousand Oaks.

Funi, C.; Paese, A. 2012. Spatial and Temporal Patterns of Deforestation in Rio Cajarí Extrative Reserve, Amapá, Brazil. PLOS ONE, 7: e51893.

IBGE. 2012. Instituto Brasileiro de Geografia e Estatística. Manual Técnico da Vegetação Brasileira. n. 1. 2nd ed., IBGE, Rio de Janeiro, 272p.

IBGE. 2021. Instituto Brasileiro de Geografia e Estatística. 2019. (https://sidra.ibge.gov.br/tabela/289\#resultado). Accessed on 12 Jun 2021.

INMET. 2021a. Instituto Nacional de Meteorologia. (http://www. inmet.gov.br/portal/index.php?r=estacoes/estacoesAutomaticas). Accessed on 12 Jun 2021.

INMET. 2021b. Instituto Nacional de Meteorologia. Normais Climatológicas do Brasil 1961-1990. (http://www.inmet.gov. $\mathrm{br} /$ portal/index.php? $\mathrm{r}=$ clima/normaisClimatologicas). Accessed on 12 Jun 2021.

Kainer, K.A.; Wadt, L.H.O.; Gomes-Silva, D.A.P.; Capanu, M. 2006. Liana loads and their association with Bertholletia excelsa fruit and nut production, diameter growth and crown atributes. Journal of Tropical Ecology, 22: 147-154.

Kainer, K.A.; Wadt, L.H.O.; Staudhammer, C.L. 2007. Explaining variation in Brazil nut fruit production. Forest Ecology and Management, 250: 244-255.

Kassambara, A. 2020. ggpubr: "ggplot2" Based Publication Ready Plots. R package version 0.4.0. (https://cran.r-project.org/ package $=$ ggpubr).
Kassambara, A. 2021. rstatix: Pipe-Friendly Framework for Basic Statistical Tests. R package version 0.7.0. (https://cran.r-project. org/package=rstatix).

Lewis, S.L.; Brando, P.M.; Phillips, O.L.; Van Der Heijden, G.M.F.; Nepstad, D. 2011. The 2010 Amazon drought. Science, 331: 554.

Levis, C.; Flores, B.M.; Moreira, P.A.; Luize, B.G.; Alves, R.P.; Moraes, J.F.; et al. 2018. How People Domesticated Amazonian Forests. Frontiers in Ecology and Evolution, 5: 171-192.

Marengo, J. 2007. Mudanças climáticas globais e seus efeitos sobre a biodiversidade. In: Raigoza, D.; Fidalgo, E.; Oliveira, J.C.M.; Faria, L.M.B. (Ed.). Caracterização do Clima Atual e Definição das Alteraçôes Climáticas Para o Território Brasileiro ao Longo do Século XXI, 2nd ed., Ministério do Meio Ambiente, Brasília, 54p.

Marengo, J. A.; Espinoza, J. C. 2016. Extreme seasonal droughts and floods in Amazonia: causes, trends and impacts. International Journal of Climatology, 36: 1033-1050.

Martorano, L.G.; Pereira, L.C.; Nechet, D. 1993. Tipologia climática do Estado do Pará - adaptação do método de Koopen. Boletim de Geografia Teorética, 23: 307-312.

Matos, F.S. Borges, L.P.; Amaro, C.L.; Oliveira, D.B.; Carmo, M.S. 2019. Folha Seca: Introdução à Fisiologia Vegetal. 1st ed. APPRIS, Botucatu, 189p.

Maués, M.M.; Krug, C.; Wadt, L.H.O.; Drumond, P.M.; Cavalcante, M.C.; Silva dos Santos, A.C. 2015. A Castanheira-do-Brasil: Avanços no Conhecimento das Práticas Amigáveis à Polinização. FUNBIO, Rio de Janeiro, 84p.

Meir, P.; Wood, T.E.; Galbraith, D.R.; Brando, P.M.; Da Costa, A.C.L.; Rowland, L.; et al. 2015. Threshold responses to soil moisture deficit by trees and soil in tropical rain forests: Insights from field experiments. BioScience, 65: 882-892.

Miranda, Z.P.; Guedes, M.C.; Batista, A.P.B.; da Silva, D.A.S. 2018. Natural regeneration dynamics of Mora paraensis (Ducke) Ducke in estuarine floodplain forests of the Amazon River. Forests, 9: 54. doi:10.3390/f9020054

Moritz, A. 1984. Estudos biológicos da floracão e frutificacão da castanha-do-brasil (Bertholletia excelsa H.B.K). Documento 29. EMBRAPA- CPATU, Belém, 82p.

Neves, E.S.; Guedes, M.C.; Rodrigues, E.G. 2015. Relação da produção de frutos de castanha-da-amazônia (Bertholletia excelsa Bonpl.) com variáveis das próprias castanheiras, em capoeira e floresta da Resex Cajari. Biota Amazônia, 2: 31-37.

Nobre, C.A. 2008. Mudanças climáticas globais e o Brasil: por que devemos nos preocupar. Revista Plenarium, 5: 12 - 20.

Novais, S.M.A.; Nunes, C.A.; Santos, N.B.; D’Amico, A.R.; Fernandes, G.W.; Quesada, M.; et al. 2016. Effects of a possible pollinator crisis on food crop production in Brazil. PLoS ONE, 11: e0167292.

Oliveira Jr., R.C.; Melem Jr., N.J.; Guedes, M.C.; Santos, D.B.; Guimarães, Y.B.P.C.; Araújo, D.M.F.; Ferreira, N.S.; Moraes, A.S. 2021. Caracterização dos Solos sob Castanhais na Região Sul do Estado do Amapá. Série Documentos (61), Embrapa Amapá. Macapá, 30p. (https://ainfo.cnptia.embrapa.br/digital/bitstream/ item/222388/1/Doc-106-Caracterizacao-Solos-V4.pdf)

Pedrozo, C.Â.; Tonini, H.; Deon, M.; Resende, V.; Schaefer, M. 2015. Repeatability of fruits and seeds production and selection 
of Brazil nut genotypes in native populations in Roraima. Revista Arvore, 39: 863-871.

R Core Team. 2020. R: A language and environment for statistical computing. R Foundation for Statistical Computing, Vienna, Austria. (https://www.R-project.org/).

RadamBrasil. 1974. Projeto Radar da Amazônia, Levantamento de recursos naturais. v.4. Folha SB.22 Araguaia e parte da Folha SC.22 Tocantins. DNPM/MME, Rio de Janeiro.

Rathcke, B.; Lacey, E.P. 1985. Phenological patterns of terrestrial plants. Annual Review of Ecology and Systematics, 16: 179-214.

Salomão, R.d.P. 2014. A castanheira: história natural e importância socioeconômica. Boletim Museu Pareaense Emílio Goeldi, 9: 259-266.

Santos, C.F. dos; Absy, M.L. 2012. Interactions between carpenter bees and orchid bees (Hymenoptera: Apidae) in flowers of Bertholletia excelsa Bonpl. (Lecythidaceae). Acta Amazonica, 42: 89-94.

Sobrinho, T.R.G. 2017. Estrutura, funcionamento e evolução das paisagens cobertas por savanas na reserva extrativista do Rio Cajari/AP, Amazônia oriental, Brasil. Doctoral thesis, Pontifícia Universidade Católica de Minas Gerais, Brazil. 308p. (http:// www.biblioteca.pucminas.br/teses/Geografia_ThemistoclesRap haelGomesSobrinho_5501.pdf)

Sullivan, M.J.P.; Lewis, S.L.; Affum-Baffoe, K.; Castilho, C.; Costa, F.; Sanchez, A.C. et al. 2020. Long-term thermal sensitivity of Earth's tropical forests. Science, 368: 869-874.

Tonini, H. 2011. Fenologia da castanheira-do-Brasil (Bertholletia excelsa Humb. \& Bonpl., Lecythidaceae) no sul do Estado de Roraima. Cerne, 17: 123-131.

Tonini, H.; Pedrozo, C.Â. 2014. Changes in annual production of fruits and seeds of Brazil nut trees (Bertholletia excelsa Bonpl., Lecythidaceae ) in native forests of Roraima State, Brazil. Arvore, 38: 133-144.

Villar, J.C.E.; Ronchail, J.; Guyot, J.L.; Cochonneau, G.; Naziano,F.; Lavado, W.; et al. 2008. Spatio-temporal rainfall variability in the
Amazon basin countries (Brazil, Peru, Bolivia, Colombia, and Ecuador). International Journal of Climatology, 29: 1574-1594.

Vogt, N.; Pinedo-Vasquez, M.; Brondízio, E.S.; Rabelo, F.G.; Fernandes, K.; Almeida, O.; et al. 2016. Local ecological knowledge and incremental adaptation to changing flood patterns in the Amazon delta. Sustainability Science, 11: 611-623.

Wadt, L.H.D.O.; Kainer, K.A.; Staudhammer, C.L. 2015. Corte de Cipós em Castanheiras como Tratamento Silvicultural para Aumentar a Produção de Frutos. Comunicado Técnico \# 400, Embrapa Rondônia, Porto Velho, 4p.

Wadt, L.H.O.; Kainer, K.A.; Gomes-Silva, D.A.P. 2005. Population structure and nut yield of a Bertholletia excelsa stand in Southwestern Amazonia. Forest Ecology and Management, 211: 371-384.

Wadt, L.H.; Lynn, C.; Kainer, K.A.; Silva, J. 2018. Primary and secondary dispersal of Bertholletia excelsa: Implications for sustainable harvests. Forest Ecology and Management, 415-416: 98-105.

Wickham, H.; Averick, M.; Bryan, J.; Chang, W.; McGowan, L.; François, R.; et al. 2019. Welcome to the Tidyverse. Journal of Open Source Software 4: 1686. doi.org/10.21105/joss.01686

Wickham, H.; François, R.L.H.; Müller, K. 2021. dplyr: A Grammar of Data Manipulation. R package version 1.0.3. (https://cran.rproject.org/package=dplyr).

Zeng, N.; Yoon, J-H.; Marengo, J.A.; Subramaniam, A.; Nobre, C.A.; Mariotti, A.; Neelin, J.D. 2008. Causes and impacts of the 2005 Amazon drought. Environmental Research Letters, 3: 014002.

Zhao, W.; Zhao, X.; Zhou, T.; Wu, D.; Tang, B.; Wei, H. 2017. Climatic factors driving vegetation declines in the 2005 and 2010 Amazon droughts. PLoS ONE, 12: e0175379.

RECEIVED: $01 / 09 / 2020$

ACCEPTED: 22/06/2021

ASSOCIATE EDITOR: Gilberto Fisch 
SUPPLEMENTARY MATERIAL (only available in the electronic version)

Pastana et al. Strong El Nińo reduces fruit production of Brazil-nut trees in the eastern Amazon

Table S1. Annual fruit production (fresh, undamaged fruit fallen on the ground below the crown projection, available for harvest in February) of Brazil-nut trees monitored in two 9-ha plots in natural stands in a forest area and a savannah/forest-transition area in the Cajari Extractivist Reserve (Resex Cajari), in southern Amapá state, eastern Brazilian Amazon. Zero (0) indicates that fruit production was monitored but no fruit was found; a dash (-) indicates that there was no monitoring in this year. DBH = diameter at breast height; STATUS: $\mathrm{P}=$ productive; $\mathrm{NP}$ = not productive throughout the study period.

\begin{tabular}{|c|c|c|c|c|c|c|c|c|c|c|c|c|c|c|}
\hline ID & $\begin{array}{l}\mathrm{DBH} \\
(\mathrm{cm})\end{array}$ & STATUS & 2007 & 2008 & 2009 & 2010 & 2011 & 2012 & 2013 & 2014 & 2015 & 2016 & 2017 & 2018 \\
\hline \multicolumn{15}{|c|}{ Forest plot } \\
\hline 1 & 50.00 & P & 3 & 24 & 29 & 0 & 16 & 11 & 1 & 22 & 46 & 8 & 7 & 5 \\
\hline 2 & 52.55 & P & 0 & 0 & 0 & 217 & 124 & 266 & 27 & 50 & 26 & 37 & 22 & 17 \\
\hline 3 & 52.87 & $P$ & 0 & 7 & 18 & 0 & 28 & 14 & 12 & 28 & 55 & 54 & 3 & 46 \\
\hline 4 & 58.28 & $P$ & 0 & 3 & 9 & 0 & 0 & 0 & 3 & 0 & 0 & 1 & 0 & 0 \\
\hline 5 & 68.47 & P & 9 & 34 & 34 & 0 & 7 & 12 & 34 & 16 & 0 & 0 & 6 & 54 \\
\hline 6 & 71.66 & P & 98 & 97 & 107 & 33 & 34 & 199 & 4 & 100 & 85 & 26 & 26 & 174 \\
\hline 7 & 74.52 & P & 248 & 190 & 200 & 134 & 144 & 209 & 93 & 0 & 211 & 132 & 174 & 127 \\
\hline 8 & 75.80 & P & 107 & 189 & 200 & 66 & 140 & 140 & 70 & 100 & 177 & 101 & 31 & 80 \\
\hline 9 & 76.43 & P & 132 & 14 & 14 & 0 & 0 & 35 & 5 & 50 & 37 & 52 & 8 & 50 \\
\hline 10 & 81.21 & P & 0 & 37 & 40 & 71 & 52 & 66 & 38 & 50 & 57 & 71 & 22 & 41 \\
\hline 11 & 81.53 & $P$ & 146 & 138 & 157 & 152 & 75 & 129 & 80 & 150 & 184 & 144 & 89 & 198 \\
\hline 12 & 81.53 & P & 50 & 54 & 56 & 98 & 79 & 81 & 93 & 75 & 145 & 137 & 33 & 105 \\
\hline 13 & 81.85 & P & 133 & 46 & 60 & 0 & 59 & 159 & 41 & 200 & 171 & 115 & 15 & 114 \\
\hline 14 & 81.85 & $P$ & 36 & 4 & 19 & 5 & 0 & 0 & 7 & 0 & 7 & 0 & 2 & 0 \\
\hline 15 & 83.12 & P & 156 & 130 & 196 & 68 & 120 & 307 & 28 & 200 & 156 & 88 & 65 & 153 \\
\hline 16 & 85.99 & P & 107 & 134 & 137 & 150 & 83 & 170 & 115 & 100 & 233 & 134 & 89 & 166 \\
\hline 17 & 88.85 & P & 0 & 52 & 52 & 49 & 30 & 35 & 41 & 25 & 109 & 103 & 41 & 110 \\
\hline 18 & 91.40 & $P$ & 0 & 41 & 46 & 7 & 5 & 43 & 7 & 18 & 35 & 12 & 10 & 19 \\
\hline 19 & 94.27 & P & 5 & 1 & 9 & 7 & 19 & 27 & 9 & 0 & 20 & 24 & 2 & 3 \\
\hline 20 & 94.90 & P & 0 & 115 & 134 & 122 & 220 & 0 & 142 & 0 & 158 & 227 & 56 & 360 \\
\hline 21 & 95.54 & P & 72 & 38 & 41 & 63 & 0 & 38 & 14 & 9 & 188 & 25 & 35 & 94 \\
\hline 22 & 95.54 & $P$ & 27 & 20 & 27 & 18 & 22 & 53 & 67 & 0 & 11 & 43 & 1 & 14 \\
\hline 23 & 97.13 & P & 0 & 17 & 22 & 0 & 33 & 71 & 39 & 75 & 70 & 49 & 9 & 26 \\
\hline 24 & 97.13 & P & 115 & 74 & 96 & 68 & 80 & 201 & 84 & 150 & 277 & 53 & 42 & 137 \\
\hline 25 & 97.77 & P & 171 & 156 & 175 & 205 & 186 & 112 & 49 & 200 & 315 & 88 & 80 & 175 \\
\hline 26 & 98.73 & $P$ & 347 & 229 & 236 & 59 & 155 & 234 & 38 & 250 & 223 & 111 & 64 & 230 \\
\hline 27 & 98.73 & P & 0 & 0 & 0 & 0 & 0 & 0 & 0 & 0 & 39 & 28 & 0 & 0 \\
\hline 28 & 98.73 & P & 155 & 121 & 146 & 124 & 50 & 172 & 43 & 75 & 149 & 59 & 53 & 115 \\
\hline 29 & 99.36 & P & 0 & 146 & 161 & 58 & 0 & 112 & 31 & 200 & 559 & 33 & 48 & 93 \\
\hline 30 & 99.68 & P & 8 & 109 & 110 & 47 & 74 & 70 & 34 & 150 & 104 & 58 & 4 & 31 \\
\hline 31 & 101.91 & P & 174 & 90 & 126 & 71 & 64 & 238 & 28 & 150 & 142 & 92 & 50 & 210 \\
\hline 32 & 101.91 & P & 97 & 105 & 117 & 48 & 27 & 141 & 4 & 150 & 229 & 56 & 27 & 111 \\
\hline 33 & 103.50 & P & 0 & 0 & 0 & 0 & 46 & 0 & 18 & 0 & 0 & 0 & 16 & 0 \\
\hline 34 & 104.46 & P & 41 & 45 & 53 & 14 & 0 & 14 & 5 & 50 & 106 & 12 & 2 & 46 \\
\hline 35 & 105.10 & P & 200 & 63 & 63 & 247 & 128 & 156 & 69 & 200 & 150 & 113 & 65 & 46 \\
\hline 36 & 105.73 & $P$ & 0 & 115 & 134 & 121 & 127 & 0 & 115 & 0 & 134 & 187 & 95 & 20 \\
\hline 37 & 107.64 & P & 160 & 68 & 81 & 153 & 192 & 201 & 96 & 225 & 192 & 140 & 60 & 161 \\
\hline 38 & 109.87 & P & 46 & 41 & 43 & 31 & 0 & 45 & 98 & 50 & 53 & 53 & 26 & 79 \\
\hline 39 & 110.51 & P & 106 & 88 & 88 & 50 & 31 & 112 & 80 & 100 & 160 & 52 & 64 & 164 \\
\hline 40 & 111.46 & P & 49 & 30 & 61 & 41 & 33 & 103 & 28 & 50 & 68 & 48 & 10 & 39 \\
\hline 41 & 112.10 & P & 56 & 25 & 47 & 39 & 0 & 6 & 32 & 50 & 22 & 44 & 34 & 0 \\
\hline 42 & 112.10 & P & 133 & 112 & 119 & 74 & 34 & 265 & 13 & 150 & 136 & 44 & 41 & 117 \\
\hline 43 & 114.65 & P & 13 & 22 & 22 & 30 & 12 & 20 & 61 & 2 & 37 & 25 & 11 & 16 \\
\hline 44 & 121.02 & $P$ & 402 & 51 & 68 & 48 & 71 & 105 & 35 & 2 & 190 & 62 & 24 & 87 \\
\hline 45 & 124.52 & P & 51 & 131 & 158 & 58 & 128 & 330 & 18 & 6 & 7 & 97 & 78 & 43 \\
\hline 46 & 125.16 & P & 619 & 478 & 516 & 162 & 241 & 681 & 142 & 400 & 506 & 285 & 271 & 375 \\
\hline 47 & 136.31 & P & 137 & 106 & 114 & 73 & 64 & 71 & 24 & 100 & 200 & 41 & 13 & 97 \\
\hline 48 & 136.31 & P & 219 & 190 & 190 & 156 & 192 & 131 & 12 & 150 & 331 & 223 & 78 & 120 \\
\hline 49 & 136.94 & P & 26 & 4 & 9 & 1 & 4 & 58 & 5 & 0 & 53 & 17 & 3 & 9 \\
\hline 50 & 137.26 & P & 164 & 94 & 102 & 13 & 232 & 287 & 161 & 150 & 300 & 148 & 53 & 30 \\
\hline 51 & 138.54 & $\mathrm{P}$ & 148 & 86 & 122 & 173 & 115 & 215 & 100 & 200 & 152 & 107 & 86 & 146 \\
\hline
\end{tabular}


Table S1. Continued

\begin{tabular}{|c|c|c|c|c|c|c|c|c|c|c|c|c|c|c|}
\hline ID & $\begin{array}{l}\text { DBH } \\
(\mathrm{cm})\end{array}$ & STATUS & 2007 & 2008 & 2009 & 2010 & 2011 & 2012 & 2013 & 2014 & 2015 & 2016 & 2017 & 2018 \\
\hline 52 & 138.54 & $P$ & 212 & 141 & 193 & 454 & 154 & 334 & 240 & 200 & 349 & 191 & 78 & 98 \\
\hline 53 & 140.13 & P & 198 & 187 & 221 & 217 & 141 & 266 & 71 & 150 & 295 & 140 & 35 & 137 \\
\hline 54 & 140.13 & P & 48 & 57 & 58 & 30 & 12 & 72 & 53 & 50 & 54 & 82 & 36 & 28 \\
\hline 55 & 140.76 & P & 0 & 79 & 220 & 211 & 40 & 285 & 182 & 200 & 315 & 297 & 88 & 123 \\
\hline 56 & 140.76 & P & 169 & 138 & 154 & 237 & 147 & 104 & 250 & 100 & 176 & 172 & 68 & 50 \\
\hline 57 & 142.36 & P & 33 & 23 & 45 & 17 & 7 & 61 & 13 & 20 & 55 & 21 & 4 & 19 \\
\hline 58 & 143.31 & P & 0 & 7 & 20 & 114 & 100 & 306 & 42 & 250 & 323 & 127 & 11 & 253 \\
\hline 59 & 144.90 & P & 48 & 35 & 37 & 28 & 27 & 55 & 49 & 50 & 66 & 69 & 19 & 33 \\
\hline 60 & 146.18 & P & 151 & 75 & 77 & 53 & 14 & 193 & 9 & 22 & 197 & 50 & 23 & 31 \\
\hline 61 & 146.82 & P & 20 & 45 & 53 & 202 & 33 & 102 & 70 & 50 & 155 & 40 & 19 & 61 \\
\hline 62 & 152.87 & P & 202 & 25 & 83 & 237 & 110 & 243 & 113 & 200 & 161 & 79 & 41 & 75 \\
\hline 63 & 152.87 & P & 282 & 79 & 179 & 162 & 194 & 267 & 84 & 250 & 113 & 229 & 96 & 60 \\
\hline 64 & 161.15 & P & 295 & 268 & 270 & 173 & 171 & 285 & 36 & 250 & 165 & 176 & 12 & 152 \\
\hline 65 & 162.10 & P & 135 & 90 & 110 & 143 & 157 & 298 & 126 & 100 & 265 & 62 & 99 & 128 \\
\hline 66 & 165.61 & P & 122 & 112 & 116 & 95 & 110 & 94 & 30 & 150 & 34 & 201 & 16 & 118 \\
\hline 67 & 165.61 & P & 181 & 213 & 226 & 113 & 20 & 193 & 69 & 100 & 316 & 55 & 20 & 174 \\
\hline 68 & 165.92 & $P$ & 112 & 14 & 138 & 37 & 87 & 193 & 16 & 16 & 66 & 24 & 26 & 39 \\
\hline 69 & 166.24 & P & 363 & 110 & 316 & 110 & 192 & 204 & 24 & 100 & 489 & 74 & 19 & 15 \\
\hline 70 & 172.61 & P & 211 & 172 & 210 & 47 & 81 & 278 & 42 & 150 & 286 & 103 & 38 & 199 \\
\hline 71 & 175.16 & P & 98 & 47 & 48 & 103 & 105 & 257 & 24 & 50 & 193 & 46 & 6 & 48 \\
\hline 72 & 177.39 & P & 0 & 0 & 0 & 0 & 0 & 0 & 149 & 0 & 417 & 181 & 28 & 116 \\
\hline 73 & 178.34 & P & 1027 & 788 & 879 & 191 & 292 & 935 & 61 & 950 & 600 & 148 & 124 & 661 \\
\hline 74 & 183.44 & $P$ & 96 & 17 & 54 & 19 & 22 & 60 & 28 & 14 & 66 & 12 & 6 & 23 \\
\hline 75 & 202.55 & P & 293 & 142 & 331 & 263 & 207 & 483 & 44 & 250 & 0 & 129 & 76 & 158 \\
\hline 76 & 226.75 & P & 213 & 224 & 225 & 458 & 153 & 300 & 190 & 250 & 376 & 264 & 79 & 83 \\
\hline 77 & 247.13 & P & 83 & 10 & 17 & 200 & 22 & 89 & 23 & 0 & 18 & 0 & 2 & 0 \\
\hline 78 & 280.25 & P & 210 & 295 & 295 & 358 & 114 & 321 & 47 & 150 & 296 & 111 & 79 & 74 \\
\hline \multicolumn{15}{|c|}{ Forest/savannah-transition plot } \\
\hline 1 & 51.57 & $P$ & - & - & - & 67 & 71 & - & 45 & 237 & 155 & 143 & 0 & 204 \\
\hline 2 & 55.70 & P & - & - & - & 0 & 0 & - & 4 & 31 & 31 & 4 & 0 & 2 \\
\hline 3 & 57.30 & $P$ & - & - & - & 0 & 0 & - & 10 & 0 & 5 & 25 & 0 & 70 \\
\hline 4 & 62.07 & $P$ & - & - & - & 0 & 9 & - & 4 & 13 & 15 & 36 & 0 & 30 \\
\hline 5 & 63.03 & $P$ & - & - & - & 2 & 12 & - & 7 & 12 & 79 & 26 & 0 & 24 \\
\hline 6 & 63.66 & $P$ & - & - & - & 21 & 8 & - & 54 & 21 & 125 & 33 & 1 & 107 \\
\hline 7 & 64.62 & P & - & - & - & 32 & 16 & - & 4 & 55 & 74 & 28 & 2 & 16 \\
\hline 8 & 65.89 & P & - & - & - & 12 & 28 & - & 26 & 45 & 170 & 19 & 0 & 41 \\
\hline 9 & 66.84 & $P$ & - & - & - & 149 & 183 & - & 98 & 301 & 321 & 182 & 1 & 46 \\
\hline 10 & 67.48 & P & - & - & - & 73 & 75 & - & 70 & 103 & 216 & 138 & 0 & 223 \\
\hline 11 & 68.12 & $P$ & - & - & - & 16 & 38 & - & 4 & 67 & 23 & 88 & 0 & 1 \\
\hline 12 & 71.62 & P & - & - & - & 0 & 17 & - & 0 & 6 & 27 & 8 & 0 & 17 \\
\hline 13 & 72.57 & P & - & - & - & 0 & 0 & - & 8 & 9 & 32 & 10 & 0 & 0 \\
\hline 14 & 76.39 & P & - & - & - & 110 & 132 & - & 183 & 321 & 254 & 190 & 11 & 394 \\
\hline 15 & 76.39 & P & - & - & - & 15 & 0 & - & 6 & 0 & 78 & 2 & 0 & 71 \\
\hline 16 & 77.03 & P & - & - & - & 11 & 0 & - & 19 & 31 & 96 & 31 & 0 & 153 \\
\hline 17 & 78.94 & $N P$ & - & - & - & 0 & 0 & - & 0 & 0 & 0 & 0 & 0 & 0 \\
\hline 18 & 79.58 & $P$ & - & - & - & 19 & 23 & - & 56 & 97 & 85 & 27 & 16 & 243 \\
\hline 19 & 81.81 & P & - & - & - & 0 & 0 & - & 0 & 8 & 55 & 7 & 0 & 0 \\
\hline 20 & 82.76 & P & - & - & - & 77 & 15 & - & 36 & 148 & 69 & 87 & 0 & 231 \\
\hline 21 & 83.72 & P & - & - & - & 17 & 0 & - & 4 & 57 & 156 & 70 & 30 & 37 \\
\hline 22 & 84.03 & $P$ & - & - & - & 9 & 0 & - & 0 & 0 & 48 & 19 & 4 & 0 \\
\hline 23 & 85.94 & P & - & - & - & 57 & 15 & - & 17 & 26 & 161 & 19 & 0 & 2 \\
\hline 24 & 86.58 & $P$ & - & - & - & 19 & 6 & - & 62 & 88 & 45 & 19 & 2 & 150 \\
\hline 25 & 86.58 & P & - & - & - & 0 & 39 & - & 13 & 60 & 43 & 4 & 0 & 7 \\
\hline 26 & 87.85 & P & - & - & - & 14 & 0 & - & 22 & 69 & 72 & 78 & 2 & 287 \\
\hline 27 & 89.13 & P & - & - & - & 70 & 37 & - & 109 & 99 & 15 & 107 & 1 & 15 \\
\hline 28 & 92.31 & P & - & - & - & 3 & 3 & - & 20 & 48 & 56 & 48 & 0 & 172 \\
\hline 29 & 92.31 & $P$ & - & - & - & 45 & 121 & - & 47 & 140 & 94 & 154 & 7 & 227 \\
\hline 30 & 93.58 & NP & - & - & - & 0 & 0 & - & 0 & 0 & 0 & 0 & 0 & 0 \\
\hline 31 & 93.90 & $P$ & - & - & - & 46 & 77 & - & 0 & 96 & 260 & 32 & 3 & 136 \\
\hline 32 & 97.40 & $\mathrm{P}$ & - & - & - & 50 & 45 & - & 19 & 53 & 27 & 27 & 1 & 69 \\
\hline
\end{tabular}


Table S1. Continued

\begin{tabular}{|c|c|c|c|c|c|c|c|c|c|c|c|c|c|c|}
\hline ID & $\begin{array}{l}\text { DBH } \\
(\mathrm{cm})\end{array}$ & STATUS & 2007 & 2008 & 2009 & 2010 & 2011 & 2012 & 2013 & 2014 & 2015 & 2016 & 2017 & 2018 \\
\hline 33 & 97.72 & $P$ & - & - & - & 62 & 55 & - & 133 & 79 & 160 & 137 & 11 & 201 \\
\hline 34 & 98.68 & P & - & - & - & 54 & 86 & - & 107 & 137 & 207 & 27 & 5 & 138 \\
\hline 35 & 98.68 & P & - & - & - & 21 & 42 & - & 14 & 27 & 45 & 62 & 2 & 207 \\
\hline 36 & 102.81 & P & - & - & - & 14 & 14 & - & 3 & 3 & 19 & 8 & 0 & 39 \\
\hline 37 & 104.09 & P & - & - & - & 0 & 0 & - & 0 & 0 & 9 & 0 & 0 & 4 \\
\hline 38 & 104.09 & P & - & - & - & 43 & 2 & - & 105 & 52 & 57 & 17 & 1 & 5 \\
\hline 39 & 105.04 & P & - & - & - & 218 & 64 & - & 194 & 158 & 145 & 327 & 1 & 568 \\
\hline 40 & 105.68 & P & - & - & - & 54 & 39 & - & 8 & 44 & 71 & 31 & 2 & 93 \\
\hline 41 & 106.00 & P & - & - & - & 106 & 13 & - & 32 & 114 & 18 & 95 & 0 & 160 \\
\hline 42 & 106.63 & P & - & - & - & 1 & 0 & - & 4 & 27 & 16 & 36 & 1 & 25 \\
\hline 43 & 107.59 & $P$ & - & - & - & 2 & 6 & - & 1 & 10 & 72 & 5 & 0 & 0 \\
\hline 44 & 110.13 & P & - & - & - & 62 & 24 & - & 0 & 40 & 55 & 13 & 0 & 50 \\
\hline 45 & 111.41 & P & - & - & - & 14 & 21 & - & 0 & 50 & 30 & 79 & 0 & 0 \\
\hline 46 & 111.41 & P & - & - & - & 139 & 5 & - & 26 & 246 & 130 & 286 & 10 & 1 \\
\hline 47 & 112.68 & P & - & - & - & 23 & 31 & - & 78 & 11 & 92 & 76 & 0 & 23 \\
\hline 48 & 113.00 & P & - & - & - & 5 & 3 & - & 7 & 0 & 63 & 7 & 3 & 40 \\
\hline 49 & 113.64 & $P$ & - & - & - & 39 & 300 & - & 260 & 543 & 294 & 285 & 0 & 361 \\
\hline 50 & 113.95 & P & - & - & - & 11 & 39 & - & 18 & 43 & 130 & 14 & 0 & 175 \\
\hline 51 & 114.59 & P & - & - & - & 4 & 10 & - & 60 & 10 & 28 & 28 & 1 & 0 \\
\hline 52 & 114.59 & P & - & - & - & 65 & 4 & - & 172 & 6 & 6 & 43 & 1 & 191 \\
\hline 53 & 114.91 & P & - & - & - & 64 & 102 & - & 39 & 171 & 186 & 56 & 1 & 174 \\
\hline 54 & 116.18 & P & - & - & - & 0 & 2 & - & 0 & 10 & 63 & 35 & 0 & 0 \\
\hline 55 & 116.18 & P & - & - & - & 13 & 0 & - & 81 & 13 & 26 & 7 & 0 & 5 \\
\hline 56 & 117.14 & P & - & - & - & 15 & 86 & - & 72 & 145 & 218 & 146 & 5 & 128 \\
\hline 57 & 118.41 & P & - & - & - & 148 & 70 & - & 174 & 273 & 93 & 305 & 0 & 0 \\
\hline 58 & 119.05 & P & - & - & - & 89 & 9 & - & 4 & 109 & 64 & 247 & 0 & 2 \\
\hline 59 & 119.05 & P & - & - & - & 25 & 99 & - & 149 & 166 & 87 & 55 & 0 & 196 \\
\hline 60 & 120.32 & P & - & - & - & 17 & 33 & - & 38 & 30 & 66 & 75 & 1 & 154 \\
\hline 61 & 121.59 & P & - & - & - & 0 & 4 & - & 4 & 6 & 39 & 11 & 0 & 0 \\
\hline 62 & 121.91 & P & - & - & - & 84 & 33 & - & 32 & 91 & 70 & 28 & 0 & 197 \\
\hline 63 & 122.55 & P & - & - & - & 0 & 21 & - & 12 & 4 & 96 & 32 & 0 & 28 \\
\hline 64 & 124.14 & P & - & - & - & 36 & 2 & - & 22 & 51 & 2 & 56 & 1 & 2 \\
\hline 65 & 124.14 & P & - & - & - & 45 & 1 & - & 0 & 19 & 41 & 71 & 1 & 0 \\
\hline 66 & 124.14 & P & - & - & - & 4 & 25 & - & 1 & 64 & 108 & 43 & 0 & 30 \\
\hline 67 & 124.78 & $P$ & - & - & - & 0 & 0 & - & 0 & 0 & 0 & 0 & 0 & 7 \\
\hline 68 & 124.78 & $\mathrm{P}$ & - & - & - & 79 & 195 & - & 87 & 123 & 268 & 98 & 5 & 294 \\
\hline 69 & 125.10 & P & - & - & - & 84 & 30 & - & 6 & 32 & 175 & 125 & 0 & 347 \\
\hline 70 & 126.37 & P & - & - & - & 156 & 328 & - & 193 & 548 & 185 & 694 & 0 & 471 \\
\hline 71 & 126.69 & P & - & - & - & 7 & 60 & - & 38 & 27 & 30 & 21 & 2 & 66 \\
\hline 72 & 127.32 & P & - & - & - & 11 & 4 & - & 0 & 39 & 87 & 10 & 0 & 89 \\
\hline 73 & 127.32 & P & - & - & - & 9 & 1 & - & 4 & 6 & 13 & 0 & 0 & 1 \\
\hline 74 & 127.32 & P & - & - & - & 24 & 0 & - & 49 & 171 & 90 & 97 & 0 & 0 \\
\hline 75 & 128.28 & P & - & - & - & 1 & 60 & - & 30 & 33 & 69 & 13 & 2 & 48 \\
\hline 76 & 128.92 & P & - & - & - & 18 & 50 & - & 9 & 12 & 63 & 15 & 0 & 30 \\
\hline 77 & 131.14 & P & - & - & - & 27 & 4 & - & 9 & 55 & 42 & 26 & 2 & 75 \\
\hline 78 & 131.14 & P & - & - & - & 42 & 21 & - & 6 & 40 & 63 & 130 & 0 & 156 \\
\hline 79 & 132.10 & P & - & - & - & 41 & 11 & - & 256 & 28 & 67 & 20 & 13 & 92 \\
\hline 80 & 132.10 & P & - & - & - & 68 & 134 & - & 115 & 236 & 110 & 76 & 7 & 117 \\
\hline 81 & 132.73 & P & - & - & - & 9 & 5 & - & 26 & 16 & 56 & 2 & 0 & 7 \\
\hline 82 & 133.69 & P & - & - & - & 23 & 21 & - & 28 & 8 & 22 & 4 & 0 & 12 \\
\hline 83 & 135.28 & P & - & - & - & 3 & 0 & - & 7 & 6 & 33 & 14 & 0 & 6 \\
\hline 84 & 135.92 & P & - & - & - & 0 & 41 & - & 0 & 32 & 128 & 21 & 5 & 121 \\
\hline 85 & 136.87 & P & - & - & - & 16 & 2 & - & 2 & 6 & 6 & 54 & 0 & 9 \\
\hline 86 & 137.83 & P & - & - & - & 134 & 54 & - & 157 & 176 & 345 & 79 & 13 & 350 \\
\hline 87 & 138.15 & P & - & - & - & 35 & 77 & - & 4 & 40 & 293 & 14 & 0 & 25 \\
\hline 88 & 138.46 & P & - & - & - & 17 & 26 & - & 1 & 39 & 102 & 27 & 0 & 122 \\
\hline 89 & 140.06 & $P$ & - & - & - & 131 & 62 & - & 185 & 154 & 302 & 337 & 0 & 360 \\
\hline 90 & 140.06 & P & - & - & - & 6 & 6 & - & 13 & 26 & 70 & 35 & 0 & 45 \\
\hline 91 & 140.37 & P & - & - & - & 19 & 10 & - & 0 & 11 & 88 & 10 & 0 & 82 \\
\hline 92 & 143.24 & $\mathrm{P}$ & - & - & - & 24 & 11 & - & 7 & 17 & 79 & 63 & 0 & 0 \\
\hline
\end{tabular}


Table S1. Continued

\begin{tabular}{|c|c|c|c|c|c|c|c|c|c|c|c|c|c|c|}
\hline ID & $\begin{array}{l}\text { DBH } \\
(\mathrm{cm})\end{array}$ & STATUS & 2007 & 2008 & 2009 & 2010 & 2011 & 2012 & 2013 & 2014 & 2015 & 2016 & 2017 & 2018 \\
\hline 93 & 143.24 & $P$ & - & - & - & 23 & 0 & - & 2 & 11 & 20 & 1 & 0 & 18 \\
\hline 94 & 143.24 & P & - & - & - & 7 & 38 & - & 22 & 26 & 80 & 32 & 0 & 57 \\
\hline 95 & 143.88 & P & - & - & - & 10 & 47 & - & 24 & 74 & 119 & 53 & 8 & 134 \\
\hline 96 & 148.01 & P & - & - & - & 4 & 15 & - & 45 & 60 & 221 & 27 & 0 & 112 \\
\hline 97 & 148.01 & P & - & - & - & 27 & 10 & - & 26 & 31 & 210 & 12 & 0 & 65 \\
\hline 98 & 149.61 & P & - & - & - & 24 & 13 & - & 28 & 77 & 91 & 46 & 1 & 86 \\
\hline 99 & 149.61 & P & - & - & - & 0 & 0 & - & 0 & 8 & 13 & 15 & 0 & 0 \\
\hline 100 & 149.61 & P & - & - & - & 10 & 3 & - & 19 & 27 & 85 & 68 & 0 & 41 \\
\hline 101 & 151.20 & P & - & - & - & 10 & 11 & - & 45 & 46 & 78 & 4 & 0 & 29 \\
\hline 102 & 152.79 & P & - & - & - & 28 & 3 & - & 9 & 19 & 0 & 60 & 0 & 16 \\
\hline 103 & 152.79 & P & - & - & - & 18 & 0 & - & 12 & 6 & 174 & 37 & 1 & 145 \\
\hline 104 & 154.38 & P & - & - & - & 97 & 33 & - & 56 & 57 & 84 & 127 & 0 & 36 \\
\hline 105 & 154.38 & P & - & - & - & 18 & 10 & - & 1 & 44 & 30 & 27 & 0 & 13 \\
\hline 106 & 154.38 & P & - & - & - & 183 & 186 & - & 159 & 262 & 235 & 183 & 116 & 315 \\
\hline 107 & 155.33 & P & - & - & - & 24 & 6 & - & 129 & 19 & 50 & 26 & 0 & 129 \\
\hline 108 & 155.97 & P & - & - & - & 2 & 20 & - & 22 & 23 & 82 & 15 & 0 & 59 \\
\hline 109 & 159.15 & P & - & - & - & 7 & 0 & - & 0 & 0 & 0 & 0 & 0 & 0 \\
\hline 110 & 159.15 & P & - & - & - & 53 & 8 & - & 33 & 13 & 22 & 32 & 0 & 41 \\
\hline 111 & 159.15 & $P$ & - & - & - & 22 & 21 & - & 14 & 22 & 56 & 50 & 4 & 42 \\
\hline 112 & 159.15 & P & - & - & - & 0 & 0 & - & 0 & 0 & 24 & 15 & 0 & 44 \\
\hline 113 & 161.06 & P & - & - & - & 0 & 2 & - & 21 & 3 & 62 & 6 & 0 & 3 \\
\hline 114 & 163.61 & P & - & - & - & 52 & 114 & - & 129 & 13 & 124 & 263 & 1 & 178 \\
\hline 115 & 164.25 & P & - & - & - & 49 & 61 & - & 8 & 67 & 94 & 20 & 0 & 67 \\
\hline 116 & 167.75 & P & - & - & - & 35 & 0 & - & 0 & 0 & 33 & 88 & 2 & 0 \\
\hline 117 & 169.34 & P & - & - & - & 30 & 81 & - & 7 & 118 & 238 & 81 & 0 & 208 \\
\hline 118 & 170.61 & P & - & - & - & 49 & 31 & - & 7 & 40 & 65 & 40 & 2 & 121 \\
\hline 119 & 171.89 & P & - & - & - & 8 & 6 & - & 6 & 93 & 9 & 80 & 0 & 0 \\
\hline 120 & 171.89 & P & - & - & - & 131 & 36 & - & 18 & 49 & 125 & 47 & 1 & 42 \\
\hline 121 & 175.07 & P & - & - & - & 7 & 7 & - & 2 & 14 & 96 & 6 & 0 & 2 \\
\hline 122 & 181.44 & P & - & - & - & 18 & 14 & - & 15 & 12 & 56 & 32 & 0 & 68 \\
\hline 123 & 183.98 & P & - & - & - & 5 & 2 & - & 28 & 41 & 9 & 32 & 0 & 17 \\
\hline 124 & 189.39 & P & - & - & - & 9 & 26 & - & 8 & 0 & 34 & 7 & 0 & 14 \\
\hline 125 & 203.72 & P & - & - & - & 11 & 66 & - & 6 & 67 & 31 & 88 & 0 & 242 \\
\hline 126 & 211.68 & P & - & - & - & 6 & 5 & - & 4 & 13 & 82 & 8 & 0 & 177 \\
\hline 127 & 222.82 & $P$ & - & - & - & 16 & 18 & - & 30 & 33 & 92 & 42 & 0 & 48 \\
\hline
\end{tabular}

